\title{
Cikkismertetés: "Spirituális vagyok, de nem vallásos": Védhet-e az egyik a másik nélkül a fiatalok egészségkockázatos magatartásával szemben?
}

\author{
Article review: "I am spiritual, but not religious": Does one without the \\ other protect against adolescent health-risk behaviour?
}

Ismertető: $\quad$ Maczali Katalin $₫$

Ismertetett cikk: Klara Malinakova, Jaroslava Kopcakova, Andrea Madarasova Geckova, Jitse P. van Dijk, Jana Furstova, Michal Kalman, Peter Tavel, Sijmen A. Reijneveld. International Journal of Public Health 2019 doi: 10.1007/s00038-018-1116-4

Beküldve: $\quad$ 2019. 03. 31.

doi: $\quad$ 10.24365/ef.v60i2.446

Kulcsszavak: egészségkockázatos magatartás; fiatalkor; vallásos részvétel; spitirualitás; HBSC kutatás

Keywords: health-risk behaviour; adolescence; religious attendance; spirituality; HBSC study

\begin{abstract}
A TANULMÁNY CÉLA
A cikkben ismertetett tanulmány célja volt megvizsgálni a spiritualitás, illetve a vallásos részvétel (templomba járás vagy egyéb vallási szertartáson való részvétel) védőhatásait a fiatalok egészségkockázatos magatartásaival szemben, erősen szekularizált környezetben.
\end{abstract}

A 2005-2006-os HBSC kutatás egyre aggasztóbb eredményeket mutatott, miszerint a részegség gyakorisága 40\%-kal növekedett mindegyik résztvevő kelet-európai országban az 1997-1998-as eredményekhez képest, főképp Csehországban, Bulgáriában, Horvátországban és Magyarországon. Így Csehországban is sürgető szükség mutatkozott a fiatalok egészség kockázatos magatartásaival szembeni védőfaktorok felkutatására.
A vallási hovatartozást tekintve Csehország speciális eset Közép-Európán belül, az ország lakosainak 76,4\%-a nem tartja magát semmilyen szervezett egyházhoz tartozónak. Ezért is vélték fontosnak a spiritualitás és a vallásgyakorlás lehetséges védőszerepének megvizsgálását.

\section{MÓDSZEREK}

A kutatás mintáját ( $n=4566)$ a 2014-es HBSC vizsgálatban részt vett fiatalok képezték. A WHO-val összefogva folytatott keresztmetszeti vizsgálat célcsoportja a 11, 13 és 15 éves cseh fiatalok voltak, így országos és reprezentatív mintát vizsgálhattak. A mérés során rákérdeztek a vallásos részvételre, a spiritualitásra, dohányzásra, alkohol-, kannabiszés egyéb drog használatra, illetve a szexuális kapcsolatok prevalenciájára. 
A vallásos részvételt a „Milyen gyakran jársz templomba vagy más vallási szertartásokra?” kérdéssel mérték, és a „legalább heti egy alkalommal” választ jelölőket tekintették vallási tevékenységben aktívan résztvevőnek.

A spiritualitást a módosított Spiritualitás Jóllét Skálával mérték, ahol a válaszok hatos skálán az „egyáltalán nem értek egyet”-től (1) a „teljes mértékben egyetértek" (6) válaszlehetőségekig terjedtek, és a magasabb végső érték, magasabb spirituális jóllétet jelentett. A kategorizálás során a 34-es vagy nagyobb pontszámot elérő válaszadókat tekintették spirituálisnak, és a maradékot nem spirituálisnak.

\section{EREDMÉNYEK}

Az eredményeket tekintve, a 4566 fiatal közül mindössze 7,2\% válaszolta azt, hogy heti egyszer vagy gyakrabban jár templomba. Az összes válaszadó közül 1202-en, azaz a válaszadók 26,3\%-a vett részt legalább egy fajta egészségkockázatos magatartásban, a templomba nem járók 26,8-a, míg a vallási tevékenységben aktívan résztvevők (pl.: templomba járók) 19,9\%-a. Erre példa, hogy az aktív vallásgyakorlók és a spirituális válaszadók kevesebb valószínúséggel dohányoznak rendszeresen, illetve a spirituális fiatalok esetében kevésbé valószínú a túlzott alkoholfogyasztás.

További eredményként mutatkozott, hogy az elmúlt havi kannabiszhasználat kissé magasabb volt a nem spirituális, de templomba járó válaszadók között, mint a nem spirituális és templomba sem járók esetében. Az egész életre szóló kábítószerhasználat prevalenciája szignifikánsan magasabb volt a nem spirituális, de templomba járóknál, mint bármely más csoportnál. Azonban a szexuális aktivitás prevalenciája jelentősen alacsonyabb volt ebben a csoportban.

Bár ez országos és reprezentatív vizsgálat volt, mégis fontos kiemelni, hogy egyrészt a vallást nem gyakorlók magas aránya $(92,8 \%)$ gyengíti a vizsgálat erősségét, másrészt az információk esetleges torzulásával is számolni kell, hiszen az adatbázist a fiatalok önértékelő válaszai adták, amelyeket a társadalom elvárásainak való megfelelési kényszer befolyásolhatott.

\section{KÖVETKEZTETÉS}

A vallásosság és spiritualitás számos módon befolyásolhatja az egészségkockázatos magatartást. Először is, az egyházak sokszor hangsúlyozzák az egyén felelősségét a teste épségére vonatkozólag, és ellenzik az olyan magatartásokat, melyek árthatnak az egyénnek. Másodszor, a vallásgyakorló válaszadók szülei jellemzően jobban monitorozzák a fiatalok viselkedéseit, ami valamilyen szinten megelőzheti a nem kívánt viselkedéseket. Harmadszor pedig, a vallásos aktivitás különböző szabadidős tevékenységekkel szokott párosulni, melyek preventívek lehetnek a kockázatos magatartásokkal szemben.

Azonban az eredmények azt is mutatták, hogy az alacsony szintû spiritualitás, mely vallásgyakorlással, templomba járással párosul, kapcsolatban állhat magasabb szintű egészségkárosító magatartással. Ezek fontos kérdéseket vetnek fel ezzel a specifikus csoporttal kapcsolatban, melyet ritkán tanulmányoznak. Néhány fiatal feltételezhetőleg úgy jár templomba vagy más vallási szertartásokra, hogy ahhoz nem társul belső meggyőződés.

Feltételezhetjük, hogy a vallásgyakorlást külső, általában a család nyomásának hatására végzik. Az így átélt diszkrepancia okozhat ezeknél a fiataloknál valamilyen vágyat a lázadásra, például egészségkárosító magatartásokban való részvételre.

Vizsgálataink azt mutatják, hogy a templomba járás és spiritualitás külön-külön limitált hatással van a fiatalok egészségkockázatos magatartásaira. A spiritualitás pedig csak akkor lehet védőhatással az egészségkockázatos magatartásra, ha az aktív vallási részvétellel párosul. 


\section{TANULSÁGOK A HAZAI SZAKEMBEREK SZÁMÁRA}

A vizsgálat eredményei támogatják azt az elterjedt elképzelést, miszerint a leghatásosabb intervenciók azok, melyek a spirituális értékek internalizációjával járnak. Kamaszkorban a kortársakkal való kapcsolat erős tényező a fiatalok viselkedésének és attitúdjének befolyásolásában. Hatásos stratégia lehet ezért a fiatalok egészségkockázatos magatartásának prevenciójában, ha olyan környezetet alakítunk ki, ahol a spirituális értékeket megosztják és tisztelik a teljes csoportban, például a cserkészeknél, vagy az ifjúsági központok különböző programjai során. Fontos lehet az itthoni, fiatalokat célzó prevenciós programokat is hasonló módon, a kortárs csoport bevonásával, közös értékek megfogalmazásával és tiszteletben tartásával tervezni. Érdemes továbbá megfontolni a szülők edukálását arról a felmerülő veszélyről, hogy a fiatalok templomba járásának erőltetése, vallási meggyőződésük hiányában súlyos károkat tud okozni a gyermekek mentális fejlődésében és egészségmagatartásában. 